\title{
Morphotectonic and sedimentological aspects in describing the relationship with ancient failure surfaces in southern part of Aizawl anticline, Mizoram, India
}

\author{
Raghupratim Rakshit ${ }^{1}$, Lalhmingsangi ${ }^{2}$, Devojit Bezbaruah ${ }^{1}$, Bubul Bharali $^{2, *}$ \\ IDepartment of Applied Geology, Dibrugarh University, Dibrugarh 786004, India \\ ${ }^{2}$ Department of Geology, Pachhunga University College, Aizawl 7960oI, India
}

\begin{abstract}
Population growth in Aizawl city has caused urban areas to expand into landslide-prone areas. These areas comprised of Bhuban Formation rocks of Surma Group and have geological features that frequently generate ground instabilities. The present study integrated with morphotectonic analysis, geotectonic characterization, role of litho-units including their sedimentological aspects and analyses of precipitation time series reveals that the southern part of Aizawl city is tectonically active and lithologically vulnerable towards landslide disaster. Greater surface slope and similar bed attitude enhance the risk of failure. The massive sandstone overlies upon weak clay surfaces that are regularly lubricated by high down pour. Even moderate rainfall can trigger the landslides. The clay layers can mobilize the geological lithosequences as a combined result of the tropical humid climate and observed weak slope stability conditions. A catastrophic landslide had killed more than 80 people and many other sliding events have been recorded in adjacent areas. Therefore, this study presents tectonic and geologic conditions which can help to predict future slides.
\end{abstract}

Key words: Aizawl; landslides; morphotectonics; sedimentology.
Received 24 August 2017 Accepted 26 October 2017

*For correspondence $\square$ : bubulearth@gmail.com

\section{Introduction}

Urban growth in Aizawl, the state capital of Mizoram, has increased the exposure of the population to landslides. The city is choking with such unplanned settlements and is now approaching towards southern part of Aizawl anticline (Fig. 1) where once the deadliest landslide events took place, few years back. Many fatal landslide events took place around many slide zones in Aizawl. The incidents occur in specific geological setting within the Mizoram fold belt, the Tertiary Surma basins. The basin was initiated due to collision between Indian and Burmese plates. The sedimentation sequence was primarily controlled by the NE subduction, ${ }^{1-3}$ and the suture closing event. ${ }^{4}$ They feature a humid tropical climate and contain very fine to medium grained, continental sedimentary rocks deposited in shallow marine environments.

The Bhuban Formation rocks are well exposed around Aizawl anticline where mostly rocks of Middle Bhuban litho-units are dominating. Sandstone and siltstone with small shale beds comprised the litho-sequence in the area. 


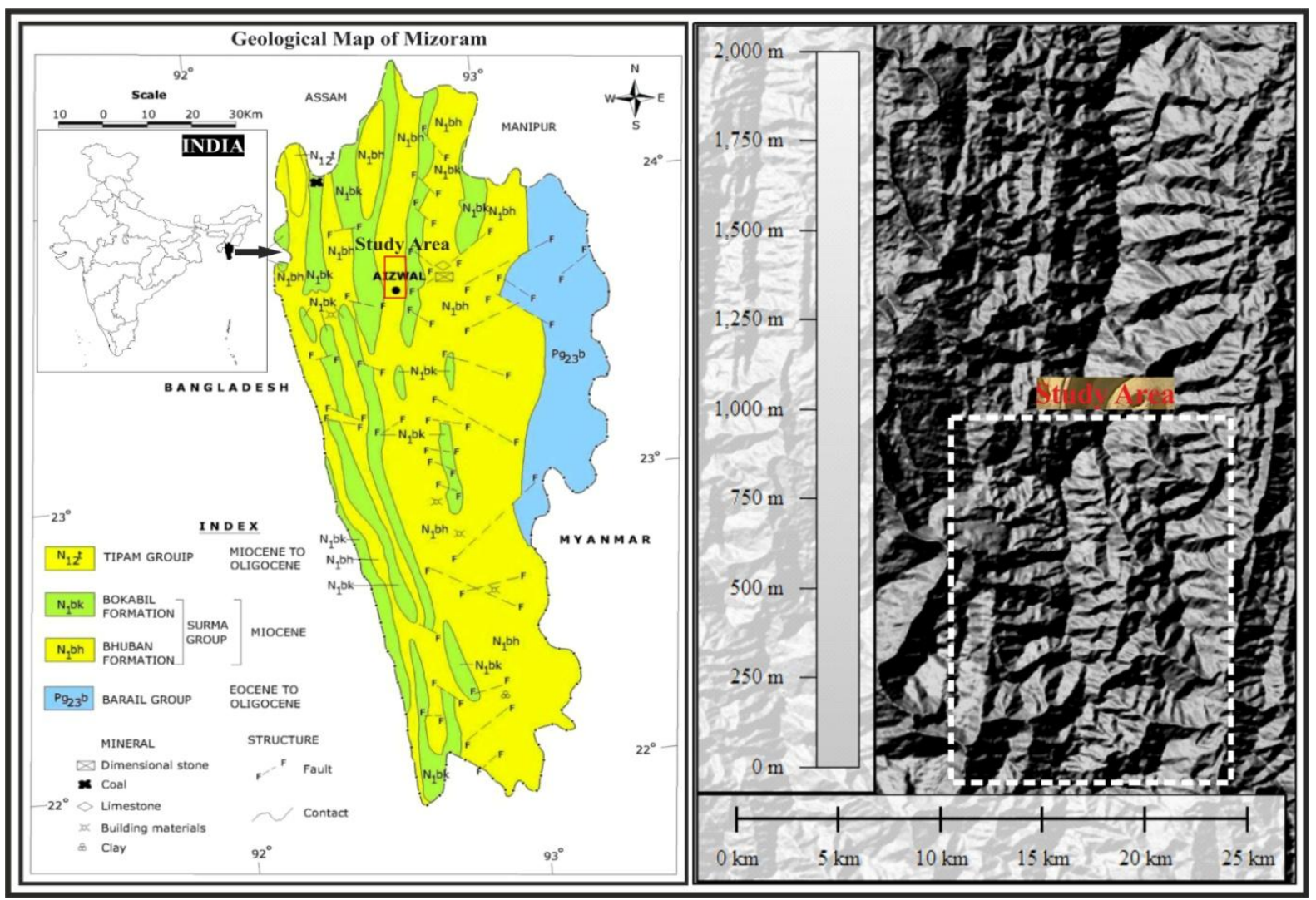

Fig. 1 | Geological map of Mizoram showing the study area.

The folding pattern due to tectonic stress, long humid climatic conditions and denudational processes make the area vulnerable for many landslide events. The western flank has greater slope than the eastern one, characteristics along with ground instability due to slope combined with rapid urban development results in creating high landslide risk zones. Most of the published studies are focused on general descriptions of specific cases in southern Aizawl and do not include morphotectonic and proper sedimentological aspects., 5 The landslide events that are considered for southern Aizawl comprises in and around Hlimen quarry, southern Hlimen and their adjacent localities.

The objective of this study is to understand the active tectonics and geological characteristics, mainly the lithological aspects of Ser Lui, Tuikhawhthla Lui and Sihpui Lui basins and their relation in triggering landslide events. We analyzed the morphotectonic parameters, delineate geological features and have tried to establish a relationship with landslide history in the area. In morphotectonic analysis, considering watershed as a basic unit is very much logical. $^{7}$ Morphometric parameters help to identify the active tectonic features and along with sedimentologic aspects could be correlated with the active and ancient landslides.

\section{Methodology}

The morphotectonic analysis using these parameters was carried out from both Survey of India (SOI) toposheets and ASTER-GDEM of 30meter resolution geo-referenced in Global Mapper v.15 software. The procedure to calculate the morphotectonic parameters are shown in Fig. 2. 


\begin{tabular}{|c|c|c|}
\hline $\begin{array}{c}\text { Morphometric } \\
\text { parameter }\end{array}$ & $\begin{array}{c}\text { Mathematical } \\
\text { derivation }\end{array}$ & $\begin{array}{c}\text { Measurement } \\
\text { procedure }\end{array}$ \\
\hline $\begin{array}{c}B_{s}, \text { drainage basin } \\
\text { shape ratio }\end{array}$ & $B_{i}=B_{l} / B_{*}$ & \\
\hline $\begin{array}{c}\text { Drainage basin } \\
\text { asymmetry }\end{array}$ & $A_{t}=100\left(A_{t} / A_{1}\right)$ & \\
\hline $\begin{array}{c}\text { Stream length- } \\
\text { gradient index }\end{array}$ & $S_{\mathrm{L}}=(\triangle H / \triangle L) L$ & \\
\hline
\end{tabular}

Fig. 2 | Mathematical derivations and procedure for calculating the parameters for each basin.

Quantitative analysis for basin morphology can be done with two basic parameters: basin shape index or elongation ratio (Bs) and circularity ratio $(\mathrm{Bc})$. The basin shape index is calculated using the formula $\mathrm{Bs}=\mathrm{Bl} / \mathrm{Bw}$, where $\mathrm{Bl}$ is the length of a basin measured from the highest point, and Bw is the width of a basin measured at its widest point. ${ }^{8,9}$ On the other hand, Circularity ratios could be calculated by the formula $\mathrm{BC}=4 \pi \mathrm{A} / \mathrm{P}^{2}$; where $\mathrm{A}$ is the basin area of the same basin order and $\mathrm{P}$ is the basin perimeter of the basin. When the value is close to 1 it indicates circular basin, whereas lower value indicates elongated basins.

Drainage basin asymmetry or asymmetric factor (AF) are indicator of tectonic deformation or tilting of the basin area under study.$^{10}$ When the value is significantly greater or less than 50 indicates effects of active tectonics or strong lithologic control. The absolute values of the asymmetry factor were calculated using formula: $|\mathrm{AF}|=\mid 50-[100$ (Ar/ At)] |; where Ar = Area of the basin belongs to right trunk of the stream and At = Total area of basin. The absolute values are grouped into four ranges- I, II, III and IV, with increasing order of asymmetry of the basins. The stream length-gradient index (SL) is calculated using the formula: $\mathrm{SL}=(\Delta \mathrm{H} / \Delta \mathrm{L}) \mathrm{L}$, where $\mathrm{L}$ is the total channel length from the midpoint of the reach -where the index is calculated- upstream to the highest point on the channel, and
$\Delta \mathrm{H} / \Delta \mathrm{L}$ is the channel slope or gradient of the reach. ${ }^{10-12}$

These calculated SL values were plotted along with the stream long-profile for each basin. From the plots we can obtain that the change in SL values with respect to the channel length is not gradual and in some instance the SL values show anomalous trend. These anomalous points are worth considering as they can indicate either structural, tectonic control or strong lithological variations. This factor is used for quantitative characterization of stream gradient conditions and to establish relationship between potential tectonic activity, topographic slope variation, rock resistance and length of the stream. ${ }^{10}$ The lineament analysis is done by extracting lineaments from toposheets and DEM and correlated their trend with major tectonic features present in the area.

Natural factors like vegetation, erosions and anthropogenic factors could hide the imprints of old landslides, which are prone to new slides. In such conditions, contour pattern study is able to recognize such zones along with active slides. Therefore, the contour patterns and their distributions were used to recognize landslides in the area. The methodologies for recognizing the landslide zones from contour pattern study is shown by Fig. 3. Ancient and active slide zones are identified using the simple methods of contour pattern, ${ }^{13,14}$ and were demarcated in different maps. Moreover, the 'five-contour rule' is maintained for better zoning of the slides or flows. ${ }^{15}$

For sedimentological study, representative sandstone samples were collected in a regular interval from the studied sections. Field data including attitude of bed rocks, sedimentary structures encountered, lithofacies variation were recorded during the field work. Vertical lithocolumn of the studied sections were prepared for better understanding of the facies distribution.

Rainfall thresholds in triggering or reactivation of landslides were obtained by precipitation time series. This analysis was performed by making a simple assessment between the cumulative rainfall recorded during the wet period 

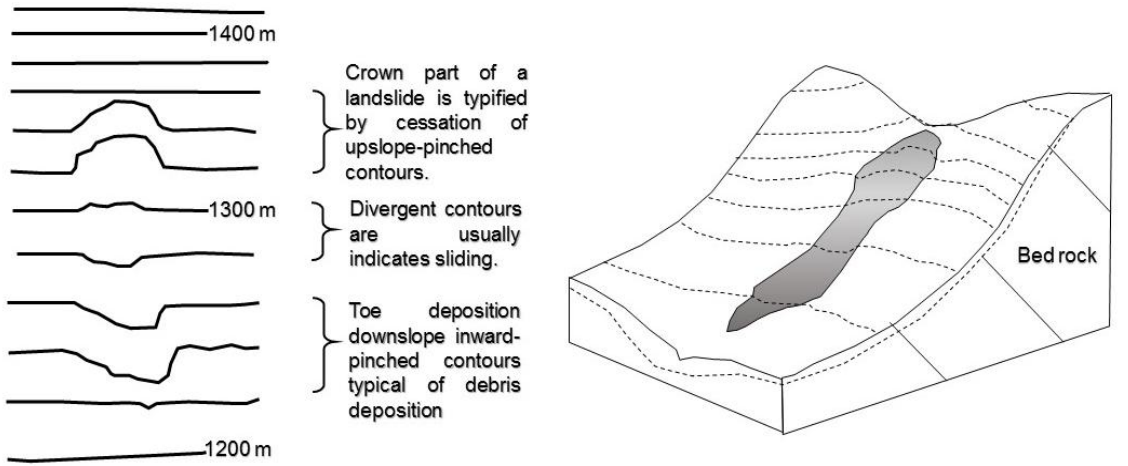

Fig. 3 | Contour patterns of the study area related with landslides.

Fig. 4 | Regional tectonic settings of the in and around IBR, the box showing the study area .

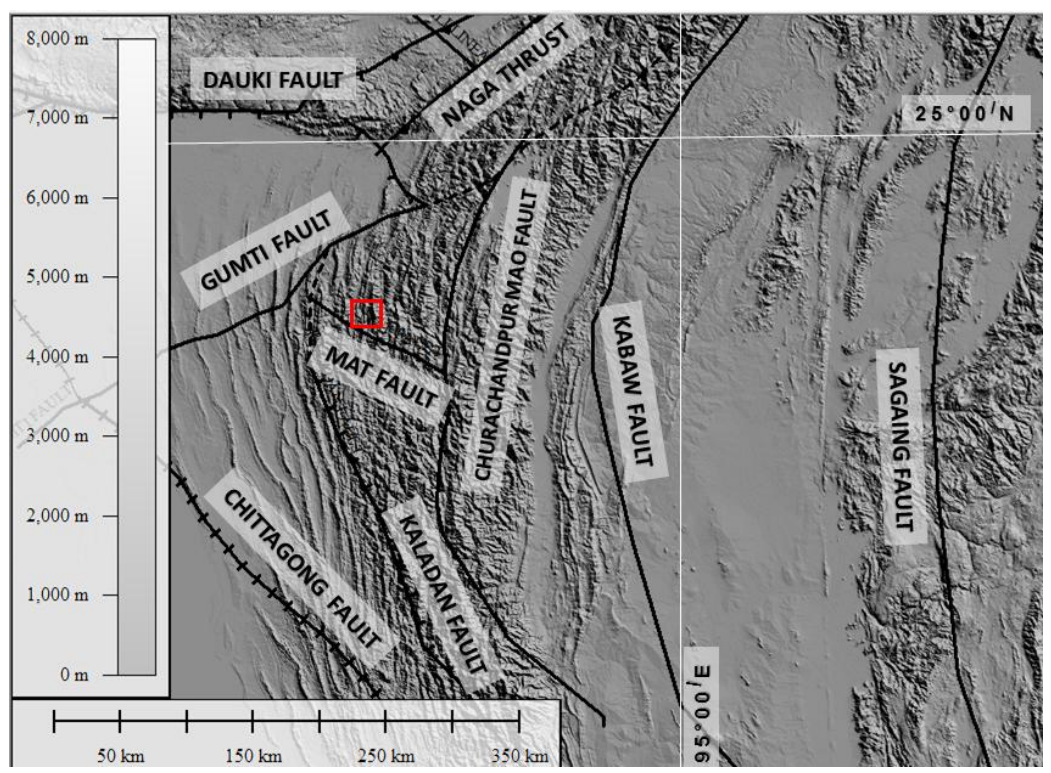

Fig. 5 | Tilting of the basins indicated by arrows and the $|A F|$ ranges for each basin.

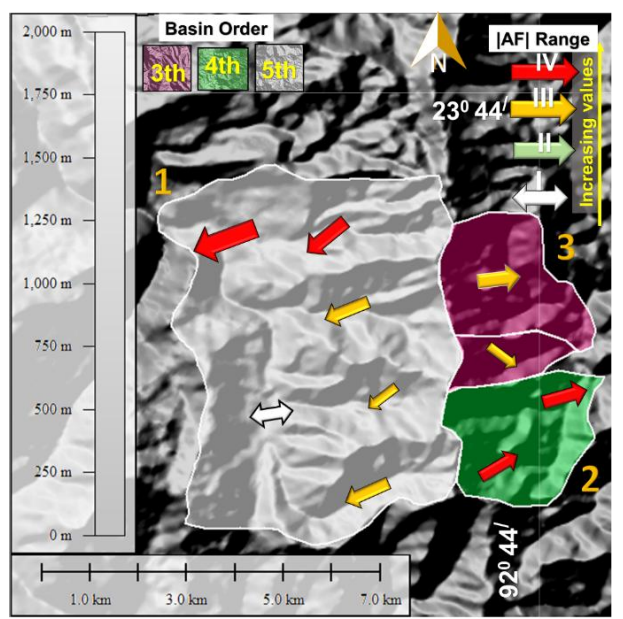


related to every landslide events and the mean rainfall for the same period when considering the existing rainfall series (1990-2007) for the study area. This method is modified from the study carried out. ${ }^{16}$

\section{Geological setting}

Indo-Burmese Range (IBR) is evolving due to active subduction of NE transversely moving Indian plate beneath Burmese plate since Late Cretaceous. The upliftment of IBR began in Late Oligocene due to this subduction process, which also gave rise to the Miocene Surma Basin. Sediments from nearby orogens get deposited along the margins of this arc and later compacted to form Tertiary rocks of Surma Group. Many faulting and thrusting events took place in later phases of the IBR evolution. In one such thrusting event, Barail Group was placed over the Surma Group of rocks. ${ }^{3}$ On western basin margin, molasse facies of Tipam Group were also found to be deposited. The area later evolved to fold-belt sequences of these litho-facies. The Aizawl anticline is one of the NS trending folded series, comprising of Surma Group of rocks. The group is divided into Bhuban and Bokabil Formations. Bhuban Formations is further sub-divided into Upper, Middle and Lower units, based on the lithologic criteria. The area is transected by many fault systems associated with Indian plate movement, slipping down along the megathrust (?). Major fault systems (Fig. 4) viz. Kaladan Fault, Gumti Fault, Churachandrapur Mao Fault, Kabaw Fault have their influence in the area. Moreover, Mat Fault that passes through the study area has direct control over geologic ambiguities that are recorded in morphotectonic study and during field investigations.

The bedding slope condition, topographic relief, high precipitations are the main factors for many sliding events occurred in the area. Western limbs of the anticline have slope surfaces dipping towards NW and SW direction. Joints and fractures in the same weak rock units are weathered easily and in some instance failed to withstand the load. In such cases the sandstone beds slip over the weaker shaly-siltstone beds to cause the landslide. Hlimen landslide is one such incident where the slide occurs along the bedding plane. This adverse bedding conditions are well observed all along the Hlimen locality with surface sloped is greater than $45^{\circ}$ and bedding planes have steep apparent dip (near about $80^{\circ}$ ) in some places with vertical joint surfaces. The geotechnical condition is poor and many more slides are eminent in near future. ${ }^{5}$ Laldintluanga et al. ${ }^{5}$ further assigned high risk potential for upper ridge part of Hlimen area, along Aizawl-Aibawk road section. Undercutting the beds for quarry reduces the stability of the area to make any and it has led to Aizawl's largest and deadliest landslides at Hlimen. ${ }^{6}$ On 9 August 1992, the disastrous landslide took place as a result of planer and toppling failure of the blocky sandstones.

\section{Results and Discussions}

\section{Morphotectonic and lineament analysis}

Different morphotectonic parameters considered to evaluate the activeness of the area. These parameters are calculated from the main three basins situated on both the flanks around southern part of anticline. The changes in drainage basins are characteristics of both tectonic and denudational processes. The morphotectonic parameters are calculate for Ser Lui, Tuikhawhthla Lui and Sihpui Lui basins are shown in Table 1. Ser Lui and its tributaries are flowing on the western part. The sub-basins shows moderate (range IV) to highly asymmetrical (range V) basins inferred by the $|A F|$ values (Fig. 5), although the southern sub-basin i.e. the upper ridges of the Ser Lui showing nearly symmetrical basins. This is because of the argillaceous lithounits are easily erodible, that can form a near symmetrical basins. In some places near the ridge the overburdens were get deposited in the foot zones of the flank that can also create symmetrical basins. Overall the main Ser Lui basin of $5^{\text {th }}$ order show highly asymmetrical, tilted basin. The semi-elongated to semi-circular basins are tilted towards SW direction. The basin shape index and circularity ratio are useful in such 
Table 1 | Morphometric parameters for the basins.

\begin{tabular}{|c|c|c|c|c|c|c|c|}
\hline 1 & Ser Lui- near Aizawl & & $\mathrm{AF}$ & $|A F|$ & $\mathrm{BC}$ & Bs & Tilting \\
\hline & $5^{\text {th }}$ & & 28.300 & 21.700 & 0.685 & 1.543 & SW \\
\hline & \multirow[t]{3}{*}{$4^{\text {th }}$ part 1} & & 31.798 & 18.202 & 0.621 & 2.481 & $\mathrm{~S}$ \\
\hline & & 3rd part 1 & 63.618 & 13.618 & 0.696 & 1.009 & SE \\
\hline & & 3rd part 2 & 42.173 & 7.827 & 0.579 & 2.315 & $S$ \\
\hline & \multirow[t]{3}{*}{$4^{\text {th }}$ part 2} & & 37.193 & 12.807 & 0.646 & 1.466 & W \\
\hline & & 3rd part 1 & 32.813 & 17.187 & 0.645 & 0.002 & SW \\
\hline & & 3rd part 2 & 41.327 & 8.673 & 0.737 & 1.487 & NW \\
\hline & \multirow[t]{5}{*}{$4^{\text {th }}$ part 3} & & 45.152 & 4.848 & 0.772 & 1.255 & W \\
\hline & & 3rd part 1 & 51.890 & 1.890 & 0.641 & 2.035 & NW \\
\hline & & 3 rd part 2 & 41.208 & 8.792 & 0.560 & 2.808 & EW \\
\hline & & 3 rd 3 & 53.098 & 3.098 & 0.724 & 1.597 & WE \\
\hline & & 3 rd 4 & 70.847 & 20.847 & 0.494 & 0.003 & SE \\
\hline \multirow[t]{4}{*}{2} & \multicolumn{7}{|l|}{ TuikhawhibaLui } \\
\hline & \multirow[t]{3}{*}{ 4th } & & 67.690 & 17.690 & 0.787 & 0.947 & SE \\
\hline & & 3rd part 1 & 62.709 & 12.709 & 0.658 & 1.960 & EW \\
\hline & & $3 r d$ part 2 & 49.342 & 0.658 & 0.687 & 1.895 & SW \\
\hline 3 & \multicolumn{2}{|l|}{ Sihpuilui } & & & & & \\
\hline & \multicolumn{2}{|l|}{$3^{\text {rd }}$} & 50.448 & 0.448 & 0.686 & 1.438 & $S$ \\
\hline
\end{tabular}

conditions as the other parameters are showing activeness of the area, still due to presence of argillaceous facies in some stretches the basins could able to attain maturity sooner. ${ }^{17}$ The arenaceous facies dominated eastern flank carries the water from both Tuikhawhthla Lui and Sihpui Lui. These basins show high to moderate $|A F|$ values that are tilting towards NE and SE respectively. Due to resistant lithologies present in this part the $\mathrm{Bs}$ and $\mathrm{BC}$ values indicate semielongated to elongated basin shape for them. The SL vs stream long-profile (Fig. 6) is drawn to delineate the anomalous points which are indicative of activeness of the area. These points are circled in the plots and are marked in the basin lineament map to understand the role of tectonic activity over such ambiguities. The lineament map superimposed on the slope shader DEM image (Fig. 7) indicates structural control around most of the places of the study area. The SL anomalous points are either laid upon them or show parallel trend as that of the lineaments. The lineament density distribution diagram (Fig. 7, inset) indicate NS and NW-SE lineament trends. These trends are similar to that of the regional fault system viz. Tuirial thrust and Mat Fault respectively. All the above points infer that the study area is tectonically active and control the topography.

\section{Sedimentological aspects of the region}

Hlimen is located in the south of Aizawl city belongs to the Middle Bhuban Formation of Surma Group. The litho association is mainly composed of massive sandstone beds with thinly bedded shale and siltstone. The representative lithocolumn is showing in the Fig. 8. The 

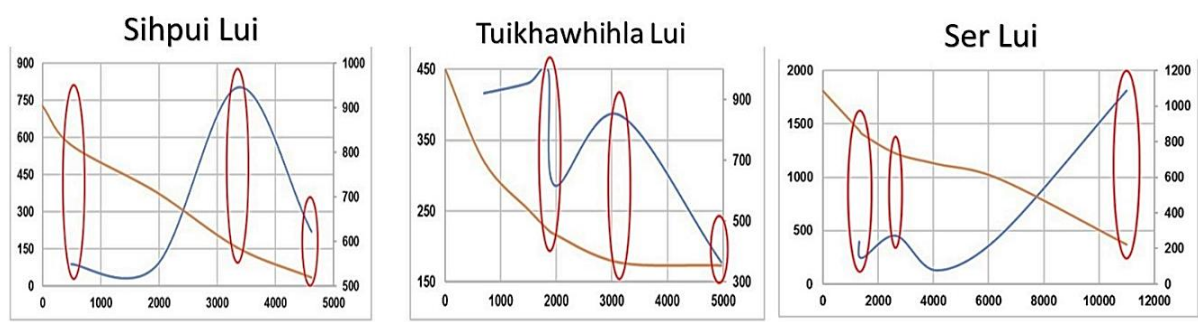

Fig. 6 | SL values plotted against river long profile, anomalous values are shown by red circles.

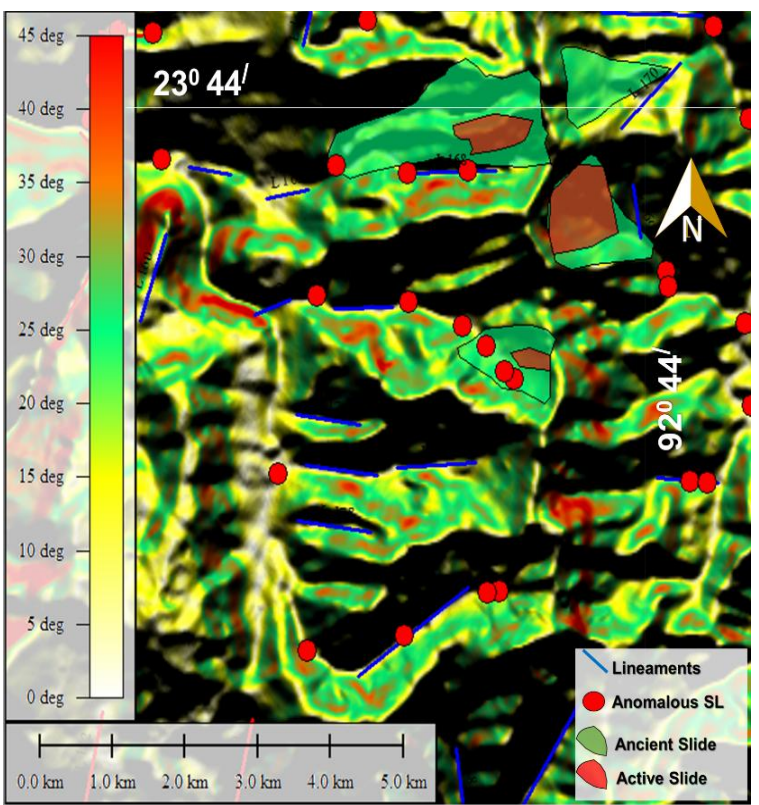

Fig. 7 | Anomalous SL points are marked in lineament map, along with ancient and active landslides. Inset is the lineament trends shown by rose diagram.

Fig. 8 | Litholog of Hlimen section.

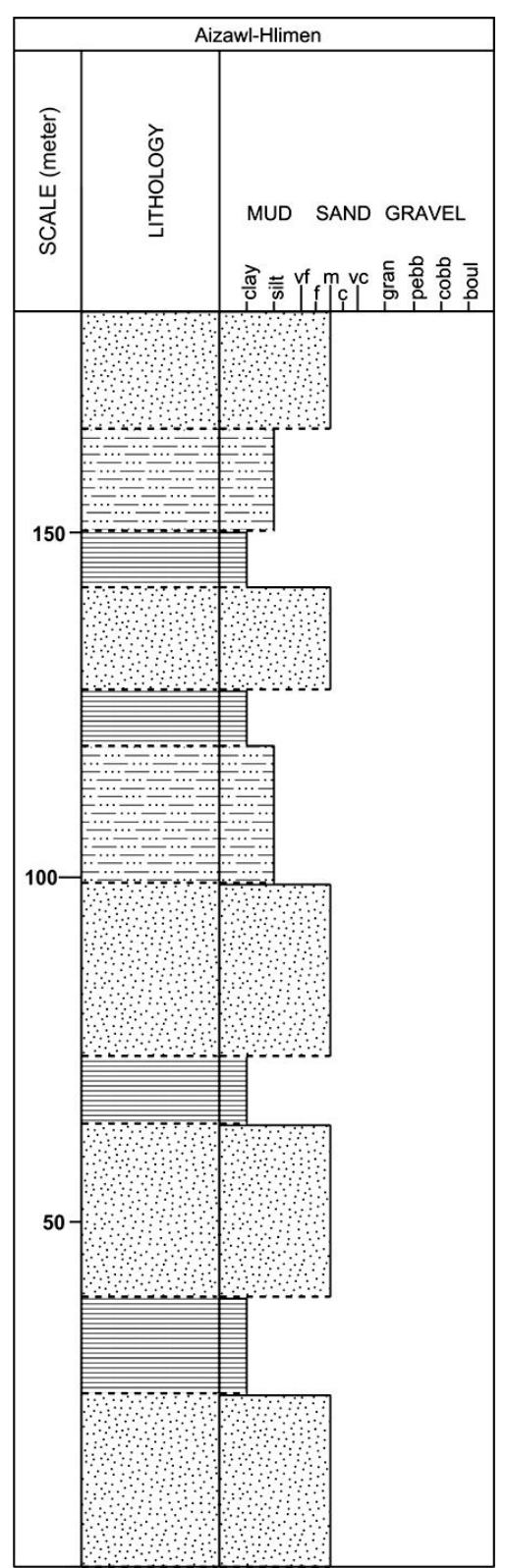


general trends of the bedrocks are oriented in $285^{\circ} / 32^{\circ}$ and $270^{\circ} / 30^{\circ}$. Hlimen area is transected by a major strike slip fault and local fold warping is also observed. Sandstones are mainly medium to fine grains which are moderately sorted. Quartzs are the most common detrital constituents among the other framework population followed by feldspars, micas and lithic fragments. Feldspars are generally less in occurrence and they are mostly weathered to sericit. The phyllosillicates included muscovite and biotite both in allogenic and authigenic varieties. Authigenic micas are generally originated from argillaceous cement and matrix. Some of the micas flakes are bended and occupying their position in between other constituent grains. Matrix is the common binding material for the framework grains which are derived during diagenesis by alteration of framework grains or precipitation of clay minerals. Moreover, cementing materials like silica, clay minerals and carbonates are also observed.

The occurrence of thinly bedded shale and siltstone in between the massive sandstones creates disturbance due to the orientation of the bed rocks. As we can see that the beds are inclined in considerable amount which can be easily triggered sliding the massive beds. The percolation of water through the weak zones of bed rocks makes clay layers weaker to uphold the shear strength which then can move the massive beds due the action of gravity. Moreover the petrography of the thin section also shows the occurrence of various forms of clays in terms of framework grains, clay matrix and cements. Therefore, it can be said that the proportion of various clay minerals within the lithoassociation is considerably high. Moreover, attitude of bed rocks is more prone to sliding over the weathered clay layers. This creates the entire area more vulnerable toward the landslide disaster.

\section{Landslide study}

Ancient and active landslides that are demarcated from contour pattern study are shown in Fig. 7. It is interesting to observe that most of the active slides are actually associated with ancient slide zones which have greater surface of influence. These ancient slide areas together with the active ones are directly related to the tectonically active anomalous zones. The topographic slope is found to be more than $35^{\circ}$ in some higher ridge areas. The most important landslide zone presents in the area is the Hlimen Landslide zone. The deadliest landslide that ever happened in whole Mizoram landslide history was on 9 August 1992 in this zone (Fig. 9). This zone is particularly active since then as more sliding events occurred in regular interval. The later sliding events occurred in the area are: 25 June 1997, 1 May 1998 and latest on 25 September 2005. During each sliding events in this area the bedding dip and topographic slope conditions were treated as chief factor. To understand this geological profile (Fig. 10) of the Hlimen slide area is prepared. The sandstone dominating rock units were found to lie upon the silty -sandstone with shale units. Moreover the bedding dip and topographic relief are high enough (more than $35^{\circ}$ in both) to achieve critical failure threshold situation very easily. The landslides in such cases are either occurred due to increase in load or decrease in shear strength along weak discontinuous surfaces. The area is also highly jointed and fractured which then can also enhance sliding and weathering effects. Triggering Hlimen landslide type events are eventually related to the precipitation conditions of the area.

\section{Time-series analysis of precipitation}

To understand the triggering factor of Hlimen landslide events, a time-series analysis of precipitation had been carried out. The data provided by DGMR and Economics \& Statistics Department, Govt. of Mizoram were used. The monthly rainfall for every year for the period 1990-2007 was taken into account to determine the mean precipitation of every month. Aizawl is located in Tropical region and therefore Indian summer Monsoon control the precipitation cycle in the area. For this study, the wettest period of a season, i.e. April to October, is taken into consideration. The monthly rainfall for every inter- 


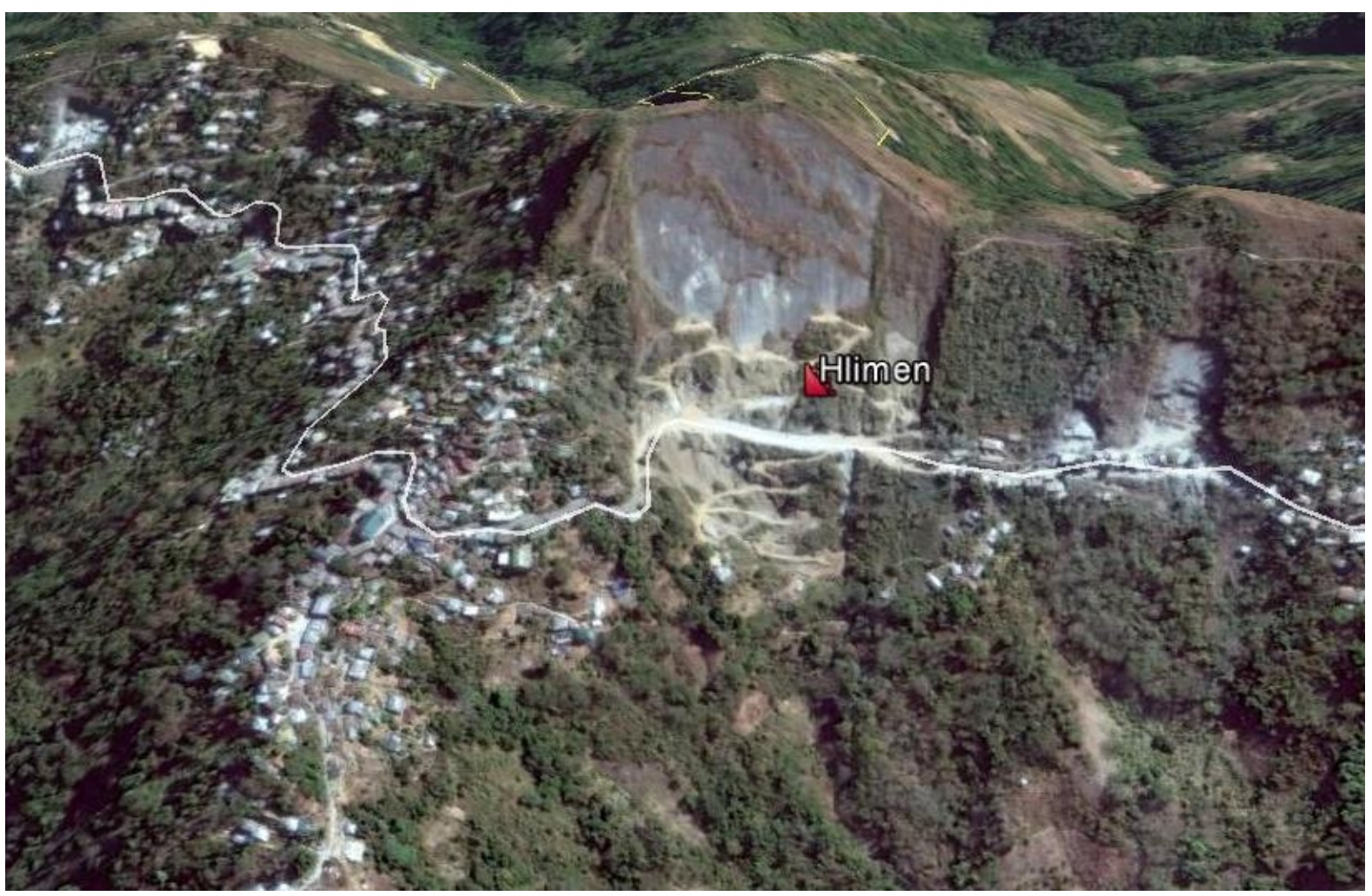

Fig. 9 | Google Earth image showing the slide zone of Hlimen quarry.

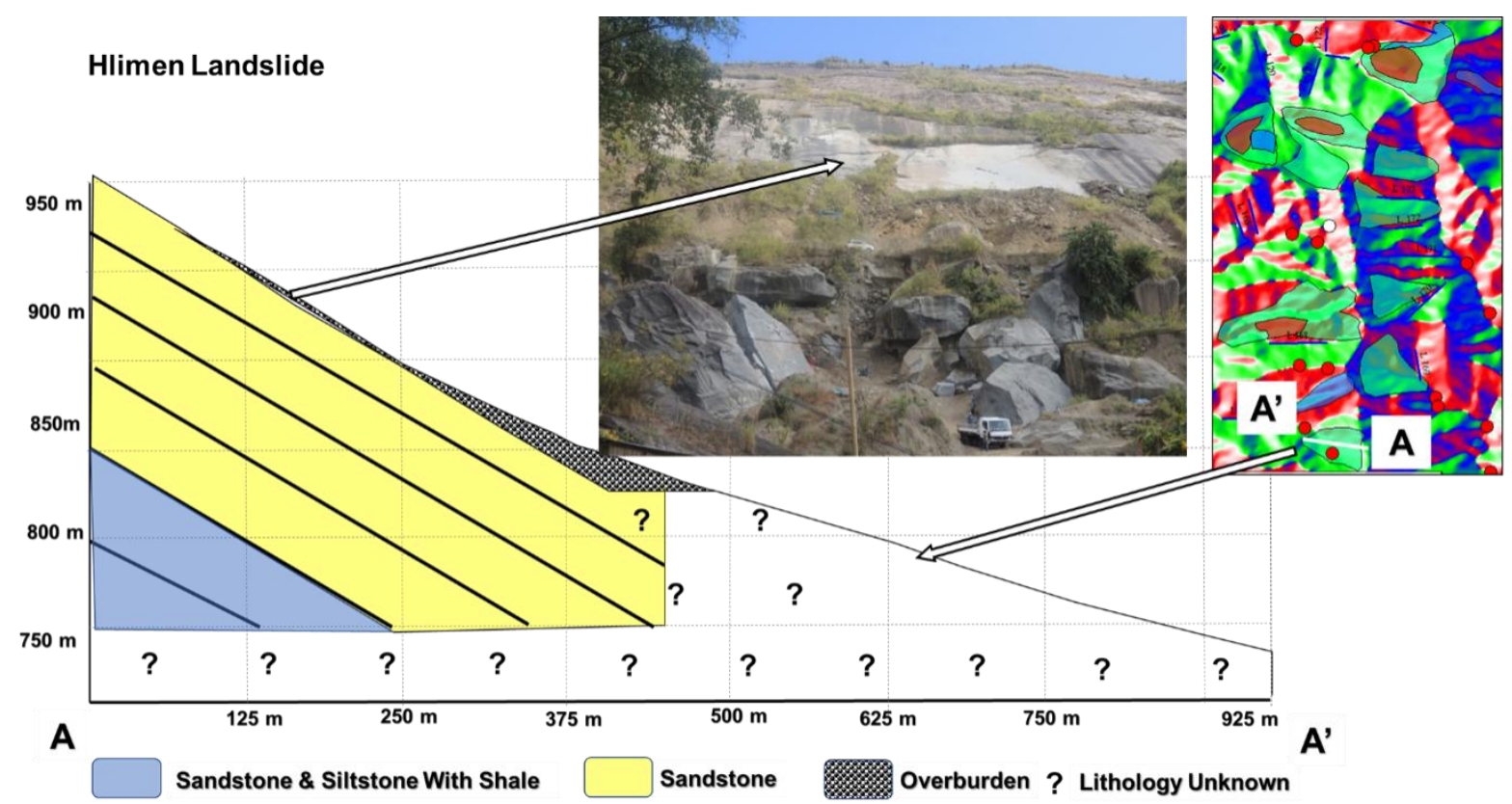

Fig. 10 | Geologic profile indicating surface slope conditions around Hlimen slide zone and southern Aizawl section. 
annual period related to each landslide events was included in Table 2.

The total rainfall precipitated during each period and their percentages with respect to the mean values were calculated. Moreover, for every dated landslide, the monthly rainfall trend was shown graphically. This consists of plotting the cumulative monthly rainfall for every interannual (blue line with circles in Fig. 11) period together with the mean value for the period (orange line with rectangles). The percentage of accumulated rainfall with respect to the mean values (green line with triangles) also plotted to understand the rainfall divergence.

Considering the mean total precipitation for the rainiest period, the 1992 event was occurred when only $67 \%$ of the mean precipitation recorded for that inter-annual period. Similarly, the later events were found to occur from 90 to $108 \%$ of the mean rainfall. Within the period from 1991-2005, many a times average monthly rainfall was recorded more than $350 \%$ of mean rainfall for that month. When the sliding events are compared, it is observed that only $145-195 \%$ of mean rainfall for that month triggers the landslide in the area (Fig. 11). The event 1 (occurred in 1992) and 4 (in 2005), were found to occur due to lowering of shear strength from lubricating of the slide surfaces from the high rainfall for few months before the event. Although it is observed that event 2 (1997) and 3 (1998) were occurred before the heaviest rainfall months. It is evident from the fact that the two events were occurred in corresponding years and in April to mid-June the rainfall even higher from $250 \%$ to $300 \%$ of monthly mean rainfall.

When correlated with other landslides around Aizawl, it is observed that most of the landslide cases where recorded during and after the peak rainfall time i.e. July. Although some landslides were recorded that occurred in premonsoon shower (Fig. 12). The fact about Hlimen landslide events show the occurrence of both before and after highest downpour of a season makes the area more vulnerable and dangerous. There are actually three sub-cycle of precipitation occurring in the area (Fig. 12), with May, July and September has higher precipitation than adjacent month.

\section{Conclusions}

The comprehensive study for the southern Aizawl city is very helpful to distinguish the vulnerability of the study area related to the tectonic activity, sedimentological criteria and pre-

Table 2 | Cumulative and total rainfall for the rainiest period covering the months from April to October.

\begin{tabular}{|c|c|c|c|c|c|}
\hline & \multirow{2}{*}{$\begin{array}{l}\text { Cumulative rainfall for } \\
\text { the mean values in } \\
\text { mm (1990-2007) }\end{array}$} & \multicolumn{4}{|c|}{$\begin{array}{l}\text { Percentage of cumulative rainfall for the interval April to October (\%) of } \\
\qquad \text { every sliding events }\end{array}$} \\
\hline & & 1991-1992 & 1996-1997 & 1997-1998 & 2004-2005 \\
\hline Apr & 165.79 & 229.81 & 127.87 & 162.86 & 306.35 \\
\hline May & 413.33 & 245.32 & 132.82 & 184.36 & 165.70 \\
\hline Jun & 366.44 & 183.93 & 147.91 & 140.81 & 143.68 \\
\hline Jul & 379.41 & 151.03 & 284.92 & 323.66 & 287.87 \\
\hline Aug & 375.26 & 172.68 & 131.11 & 132.44 & 148.67 \\
\hline Sep & 322.70 & 189.65 & 292.84 & 185.00 & 224.45 \\
\hline Oct & 159.91 & 274.53 & 161.34 & 100.06 & 195.23 \\
\hline $\begin{array}{l}\text { Mean total rainfall } \\
\text { for Apr-Oct (mm) }\end{array}$ & 288.34 & 206.71 & 182.69 & 175.60 & 210.28 \\
\hline $\begin{array}{l}\% \text { related to the } \\
\text { mean total rainfall } \\
\text { for Apr-Oct } \\
(288.34 \mathrm{~mm})\end{array}$ & & 67.20 & 105.86 & 90.14 & 108.64 \\
\hline
\end{tabular}




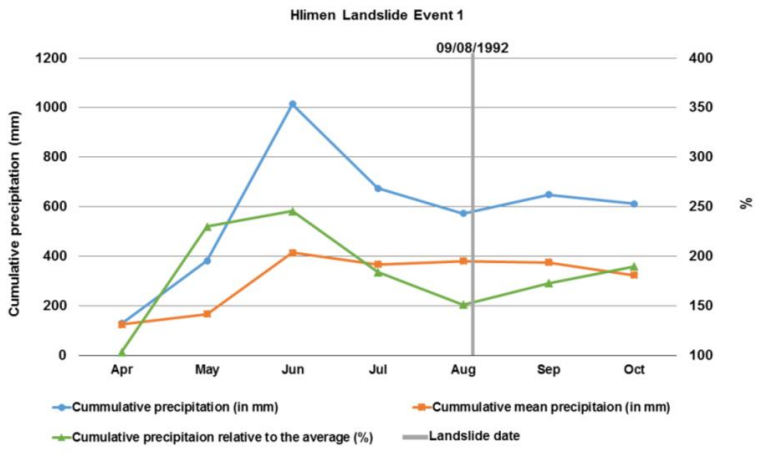

Fig. 11(a) | Cumulative rainfall for the rainiest period affecting Hlimen Landslide Event-1.

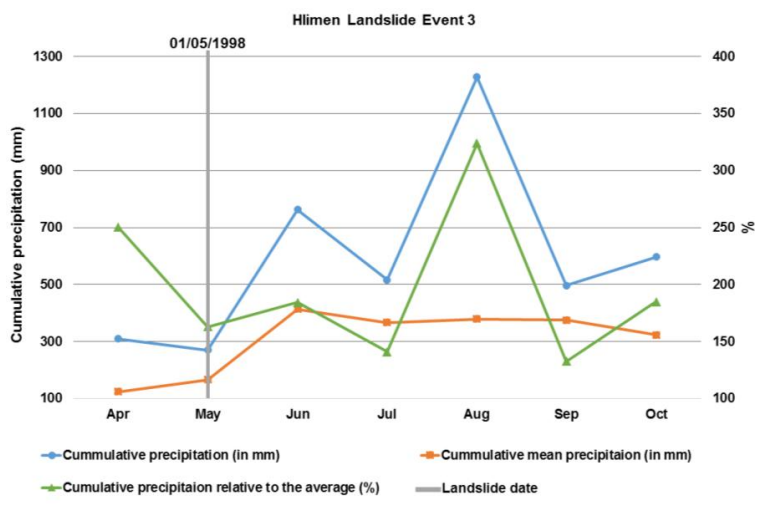

Fig. 11(c) | Cumulative rainfall for the rainiest period affecting Hlimen Landslide Event-3.

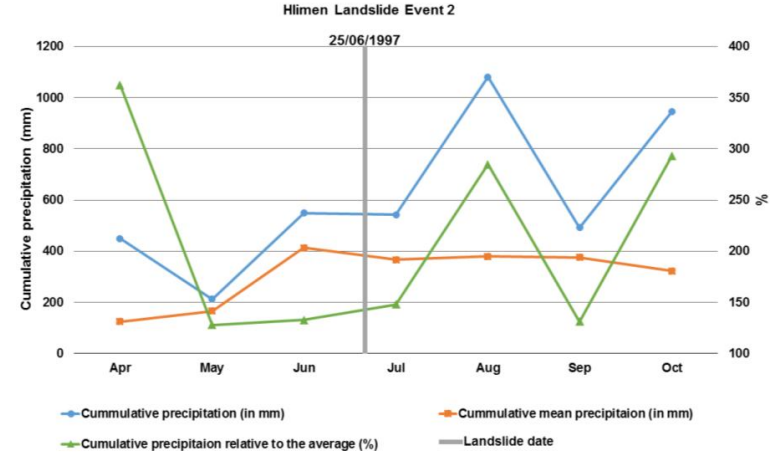

Fig. 11(b) | Cumulative rainfall for the rainiest period affecting Hlimen Landslide Event-2.

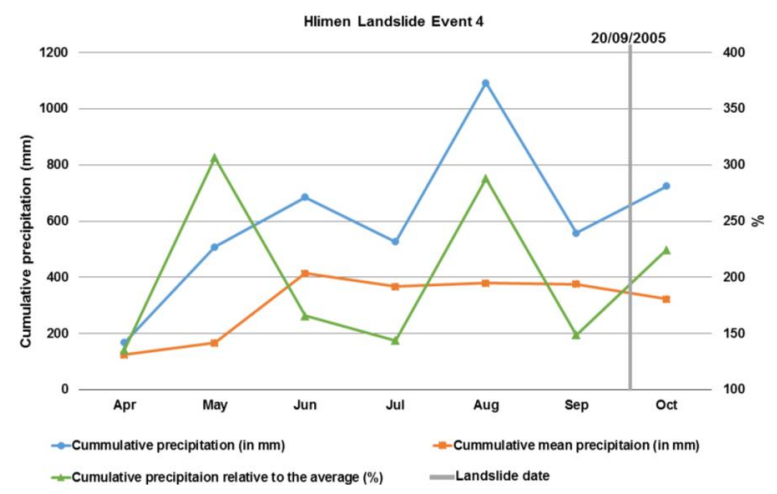

Fig. 11(d) | Cumulative rainfall for the rainiest period affecting Hlimen Landslide Event-4.

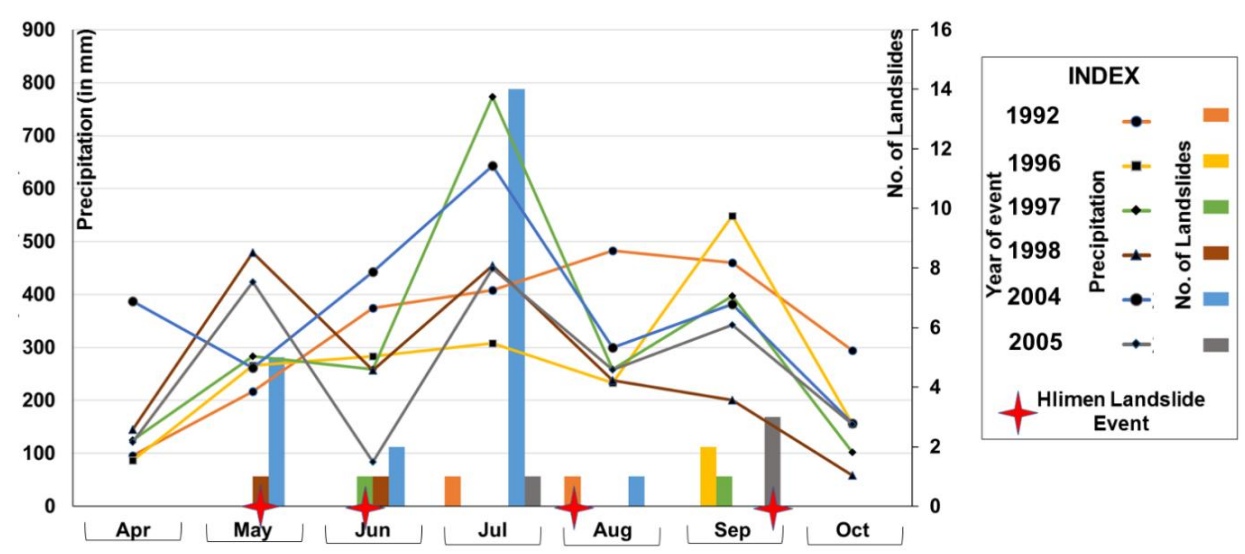

Fig. 12 | Average rainfall for the rainiest period and no. of landslides in Aizawl during years associated with Hlimen landslide events Landslide events. 
cipitation threshold. In this part of Aizawl city urbanization should be done very cautiously and for that the present study can help a lot to make a proper planning in a more scientific way. The morphotectonic analysis has been carried out for the first time to understand the tectonic activity around the sliding zones. The AF, Bs, BC and SL indices indicate the whole southern $\mathrm{Ai}$ zawl is tectonically active and the ridges where the topographic slopes are in unfavorable conditions, more vulnerable to landslides. The anomalous SL points which show strong tectonic control are also directly related to the landslides zones. Moreover, the lithologic variability cause more havoc to it. Presence of clay minerals along with phyllosilicates can create weak surfaces for sliding of the massive sandstone beds.

The humid conditions and high precipitation enhanced the weathering effects of the area. The demarcated ancient landslides along with active ones are more vulnerable zones and should be avoided for any disturbances. The roles of precipitation in triggering the ancient landslides have been carried out for all four recorded landslides around the southern Aizawl city. It is observed that in the tectonically active subsurface conditions along with the vulnerable geologic settings, the high topographic slope conditions cause many sliding events. All these events were taking place even when the rainfall in the region is less than the mean rainfall. The threshold precipitation for the region varies and therefore in some cases the accumulated rainfall during inter-annual period lubricated the slip surface, to initiate slides in pre-monsoon rain.

The knowledge for landslide occurrences depending on the geotechnical and slope stability is not absolute and, therefore, morphotectonic along with sedimentological criteria, combined with precipitation, induced landslides modelling is important to decipher the potential vulnerable zone to build safer Aizawl city.

\section{Acknowledgement}

R.R. is thankful to the UGC for providing JRF Scholarship.

\section{References}

I. Ganju, J.L. (1975). Geology of Mizoram. Geology. MineralES Meteorological Society. India, Bulletin 48, 17-26.

2. Nandy, D.R., Dasgupta, S., Sarkar, K. \& Ganguly, A. (1983). Tectonic evolution of Tripura-Mizoram Fold Belt, Surma Basin, Northeast India. Quaternary Journal. Geology, Mineral ES Meteorological Society, India 55-4, I86-I94.

3. Dasgupta, S. (1984). Tectonic Trends in Surma Basin and possible genesis of the folded belt. Records GSI $\mathbf{I n}_{3}$ (IV), 58-6I.

4. Alam, M., Alam, M.M., Curray, J.R., Chowdhury, M.L.R. \& Gani, M.R. (2003). An overview of the sedimentary geology of the Bengal Basin in relation to the regional tectonic framework and basin-fill history. Sedimentary Geology is5, 179-208.

5. Laldintluanga, H., Lalbiakmawia, F. \& Lalbiaknungi, R. (2016). Landslide hazard zonation along state highway between Aizawl City and Aibawk Town, Mizoram, India using geospatial techniques. International Journal of Engineering Sciences ES Research Technology $\mathbf{3 4 2 .}$

6. Janise, R \& Thomas, T. (2014). Building resilience to earthquakes and landslides in Aizawl, India. The Leading Edge. Special Ed. Humanitarian Geophysics $1364-$ I370.

7. Romshoo, R.A., Bhat, S.A. \& Rashid, I. (2012). Geoinformatics for assessing the geomorphological control on the hydrological response at watershed scale in Upper Indus Basin. Earth System Science I2I (3), 659-686.

8. Bull, W.B. \& McFadden, L. (1977). Tectonic geomorphology north and south of the Garlock fault, California. In: Geomorphology in Arid Regions. (Dohering D. O., Ed). Publication in Geomorphology, State University of New York, Binghamton. pp. II5-I28.

9. Ramírez-Herrera, M.T. (1998). Geomorphic assessment of active tectonics in the Acambay Graben, Mexican volcanic belt. Earth Surface Processes and Landforms 23, 317-332.

Io. Keller, E.A. \& Pinter, N. (2002). Active Tectonics: Earthquakes, Uplift, and Landscape. 2nd edition. New Jersey: Prentice Hall.

II. Azor, A., Keller, E.A. \& Yeats, R.S. (2002). Geomorphic indicators of active fold growth: South Mountain-Oak Ridge anticline, Ventura basin, southern California. Geological Society of America Bulletin II4-6, 745-753.

I2. Hack, J.T., (1973). Stream-profile analysis and streamgradient index. United States Geological Survey Journal 
of Research I (4): 42I-429.

13. Rogers, J.D. \& Doyle, B.C. (2004). Mapping of seismically-induced landslippage in the Benton Hills and Crowley's Ridge, New Madrid Seismic Zone, Missouri and Arkansas. USGS Publications.

I4. Rogers, J.D. \& Chung, J.W. (2016). Mapping earthflows and earthflow complexes using topographic indicators. Engineering Geology, 208, 206-213.

I5. Wills, C.J. \& Mc Crink, T.P. (2002). Comparing landslide inventories: the map depends on the method. Environmental ES Engineering Geoscience 8-4, 279-293.
I6. Irigaray C, Lamas F, El Hamdouni R, Fernández T \& Chacón J. (2000). The importance of the precipitation and the susceptibility of the slopes for the triggering of landslides along the roads. Natural Hazards 21, 65-8I.

17. Rakshit, R. \& Bezbaruah, D. (2016). Morphotectonic aspects in and around Aizawl, Mizoram of NE India. South East Asian Journal of Sedimentary Basin Research 2-3-4, 28-36. 